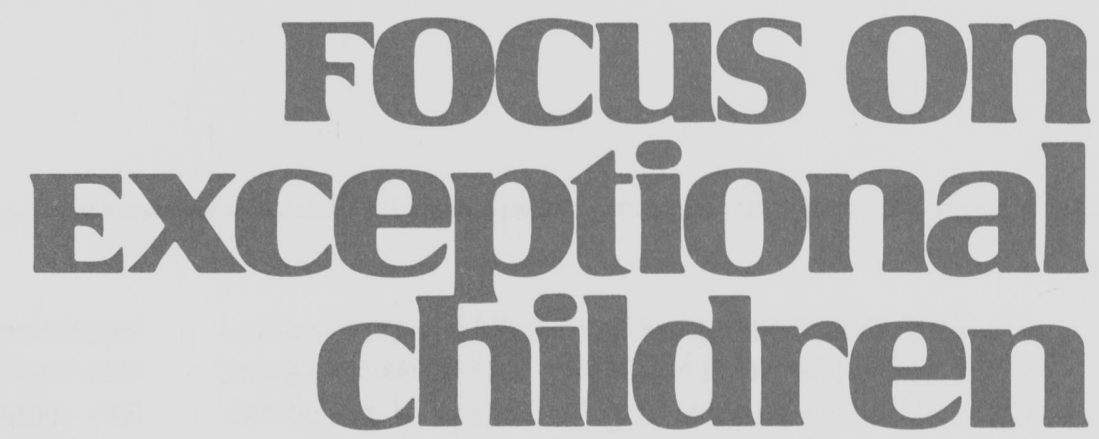

\title{
Opening the Door Further: Integrating Students with Complex Health Care Needs
}

\section{Donna H. Lehr and Pat McDaid}

"I have taught fourth grade for the past 18 years and continue to love the challenges teaching involves. This year a challenge presented itself that really frightened me. I was told that among my new students for the upcoming year would be a boy who had been seriously injured in an automobile accident. He had spent much of the past year in our local children's hospital recuperating from the injuries. The records indicated that he was very bright and, with the help of the hospital teachers, had been able to keep up with school work. Because he had continuing health care needs, his family, who had lived in a rural part of the state, had moved into this district to be closer to the hospital.

"I was concerned about this student's health care needs, including the need for continuous oxygen to assist him in breathing and the need to be fed through a tube directly into his stomach.

"When I was told he was going to be in my class, my questions were endless. Why was he coming to this school? Wasn't he too sick to come to school? Since he still had so many medical needs, why wasn't he in a hospital? Or if not a hospital, why not a convalescent hospital or a nursing home, or at home?

"Who was going to feed him? An oxygen tank in the classroom? Could he take gym? What would we do in case of an emergency? What would we tell the other children? Help! And where was I going to get that help? From special education?"

Mrs. Philpot, fourth-grade teacher, anywhere in the country

The number of children who are considered to be technology dependent has been increasing (Office of Technology Assessment, 1987). We have known that changes in educational trends would result in inclusion of students with greater diversity, including those considered to be medically fragile or having special health care needs (Lehr \& Noonan, 1989; Sirvis, 1988). These include children who present medical needs that are more intense than those which have been traditionally dealt with in schools. Our primary focus is on children dependent on medical technology such as tube feeding, ventilation, suctioning, and catheterization.

Donna Lehr is an associate professor in the Department of Special Education at Boston University. Pat McDaid is a doctoral student in the Department of Special Education at Boston University. 
Since first recognizing the trend in the late 1980s (Council for Exceptional Children, 1988; Koop, 1987; Viadero, 1987), we have been discussing the issues related to educating this population of students in both the professional literature (Lehr \& Macurdy, in press; Lehr \& Noonan, 1989; Sirvis, 1988; Sobsey \& Cox, 1991) and in the courts (Department of Education, State of Hawaii v. Dorr, 1983; Detsel v. Board of Education, 1987; Tatro v. Irving Independent School District, 1984). While specific data are difficult to ascertain, the numbers of students with complex health care needs who are being educated in schools are continually increasing (Lehr, 1990a; 1990b; Lehr \& Noonan, 1989; Sirvis, 1988; Sobsey and Cox, 1991; Urbano, 1992).

Mrs. Philpot's conversation, while fictional, is based on conversations overheard in public schools throughout the country. Eighteen years ago, when Mrs. Philpot was studying elementary education in college, the idea of educating students with complex health care needs was considered farfetched. The same thing was true when her building prin-

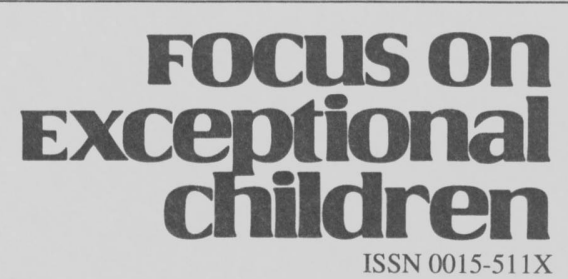

FOCUS ON EXCEPTIONAL CHILDREN (USPS 203-360) is published monthly except June, July, and August as a service to teachers, special educators, curriculum specialists, administrators, and those concerned with the special education of exceptional children. This publication is annotated and indexed by the ERIC Clearinghouse on Handicapped and Gifted Children for publication in the monthly Current Index to Journals in Education (CIJE) and the quarterly index, Exceptional Children Education Resources (ECER). It is also available in microfilm from Xerox University Microfilms, Ann Arbor, MI. Subscription rates: Individual, \$27 per year; institutions, \$36 per year. Copyright (C) 1993, Love Publishing Company. All rights reserved. Reproduction in whole or part without written permission is prohibited. Printed in the United States of America. Second class postage is paid at Denver, Colorado. POSTMASTER: Send address changes to:

Love Publishing Company

Executive and Editorial Office

1777 South Bellaire Street

Denver, Colorado 80222

Telephone (303) 757-2579
Edward L. Meyen

University of Kansas

Richard J. Whelan

University of Kansas Medical Center
Stanley F. Love Publisher
Glenn A. Vergason Georgia State University

\author{
Holly T. Rumpler
} Senior Editor cipal, her superintendent, and even her school nurse were educated-and even when the newest member of the faculty completed his program just 3 years ago.

How did we get to this point of educating students with complex health care needs in regular schools and why? What are we doing to assure that the health care, educational, social, and emotional needs of these student are being met? We intend to address the questions that many, including Mrs. Philpot, are asking.

\section{HOW DID WE GET HERE?}

"Why is he here in my class?" asked Mrs. Philpot.

The education of students with complex health care needs represents yet another step along the road to including all students in their home school districts and schools with their brothers, sisters, and friends. This trend can be traced to two sources. Changes in medical technology are enabling children with medical complications to survive newborn or posttraumatic periods. Sometimes, however, survival is accompanied by the ongoing need for intensive health care services (Lehr, 1990a; Lehr \& Noonan, 1989; Sirvis, 1988). A second source is our generally increasing practice of normalizing lives for student through the specific practice of including students with more severe disabilities into general education settings (Stainback \& Stainback, 1992).

These students, like many with disabilities, have followed the same course from most restrictive to less restrictive educational placements. Initially, all children with complex health care needs were educated in restricted, segregated settings such as hospitals, convalescent hospitals, or pediatric nursing homes where qualified personnel could meet their specialized health care needs. The families of students with special health care needs were placed in situations where they had to keep their children in restrictive placements, depending on their children's health care needs, despite the fact that their children's educational needs were often neglected. They had to choose between the medical and health needs of their children or the educational needs of their children.

Movement to less restrictive care settings has been brought about by several factors. Private insurance companies, eager to reduce the cost of health care reimbursement, have encouraged home health care of children (Urbano, 1992). At the same time, however, public assistance for health care coverage (Medicaid) required that children remain in hospital or convalescent home settings to receive funding, despite the fact that hospital-based care was more 
costly than home-based care. Changes in funding was forced by parents. Compelled by the notion of family-centered care and normalization of life for their child and family, one family requested a waiver of the Medicaid rules stipulating only hospital treatment. President Ronald Reagan signed an executive order granting the waiver. The child, Katie Beckett, was provided with money for health care coverage at home (Shelton, Jeppson, \& Johnson, 1987; Urbano, 1992).

Subsequent programs and policies resulted in an increase in the number of children previously living in an institution who could live at home in family settings. However, while new or revised funding mechanisms have increased the number of children at home, some regulations continue to be: (a) restrictive, preventing the movement of children to less restrictive settings; (b) difficult to negotiate; and (c) far from comprehensive in covering all necessary costs (Levy \& Pilmer, 1992).

Continuing along the course to greater normalization and inclusion, once delivery of complex health care at home was demonstrated to be appropriate, the next question was whether the home was the only place the care could be delivered. Couldn't procedures be worked out so children could take their equipment to school with them? After all, the equipment had gotten smaller and more portable, and since the health care procedures could be delivered at home, they obviously didn't require the specialized setting of a hospital for delivery. In many cases, parents were implementing the procedures at home, indicating that the procedure was not that complex. If a parent could do it, couldn't a teacher do it (Department of Education, State of Hawaii v. Dorr, 1983; Lehr \& Noonan, 1989)? Or if a child could receive Medicaid-funded health care at home, couldn't the nurse providing the services go to school with the child and deliver the care there (Golinker, 1991)?

Students with complex health care needs began attending school. Sometimes they entered segregated special educational settings, sometimes regular educational classes. While a greater proportion of students with complex health care needs also have disabilities requiring special education services, not all children with complex health care needs have special educational needs as defined by PL 94-142 (Council for Exceptional Children, 1988). In a recent study of a sample of school districts in California, Lynch, Lewis and Murphy (1992) reported that, on the average, only $31 \%$ of the students in their district who were considered to have chronic illnesses were identified as having special education needs. Eightyfive percent of these students were in regular educational classrooms and received no special educational services.
Educating students with complex health care needs presented a great challenge to school administrators (Viadero, 1987). The newness of the situation - the uncharted territories - facing school administrators created what seemed like insurmountable issues. The barrage of questions articulated by teachers such as Mrs. Philpot is to be expected. Few educators have had personal or professional experience with such health care procedures as tube feeding, suctioning, catheterization, and ventilation.

\section{HOW DO WE MEET THE NEEDS OF STUDENTS WITH COMPLEX HEALTH CARE NEEDS?}

"Now that I understand how this student got here, where do we begin to meet his needs?

I'm not even sure what they are!" Mrs. Philpot.

The goal for children with complex health care needs as well as all children is the provision of health and a safe environment in school. While school districts have always provided school health care services, they have not provided extensive health care. The focus has typically been on health education, environmental management, and health services restricted to accident prevention, first aid and health screening (Urbano, 1992). For students with complex health care needs, the standard policies, relating to first aid, medication administration, immunizations, and school attendance related to contagious diseases, were insufficient to meet the unique and extensive health care needs these students required.

Students with complex health care needs have the same basic needs as all children. Several other needs exist, however, that relate to the students' health care requirements: These include:

$\square$ the need to be provided with a free appropriate educational program

$\square$ the need to be provided with an education in the least restrictive environment

$\square$ the need to have a health care plan as part of their educational program

$\square$ the need to be treated as a child first, then as a student, and not as a patient

$\square$ the need to interact with other children with and without similar health care needs (Lehr, 1990a, p. 112).

We now have several years' experience in educating students with complex health care needs in schools. We have 
learned something about meeting students' basic and unique needs in least restrictive environments. We have answered the questions asked by Mrs. Philpot concerning conditions for students with complex health care needs: who should be responsible for implementing the health care; how do we prepare personnel to implement the care; what is the relationship between health care and educational service provision and student transportation (Lehr, 1990a). We have learned that successful programs develop transdisciplinary teams that are responsible for developing specific plans to address the unique health care and educational needs of the students.

\section{TEAM PLANNING AND COORDINATION}

\section{"Who's going to help me figure out the answers?"}

Teamwork is the most essential aspect of including students with complex health care needs in the public school, and it occurs long before students ever cross the threshold of the school building. Mrs. Philpot asked many questions for which there are no pat answers. It is through a transdisciplinary team of professional and family members that many districts are answering the multitude of questions that arise.

Sobsey and Cox (1991) discussed the rationale for transdisciplinary teaming designed to meet the needs of students with special health care needs in the schools:

Together the parent, nurse, and special educator can plan, implement, and evaluate the response of the students with special health care needs better than each can individually. With full communication and support of the physician and the school administrator, decisions can be reached collaboratively regarding how to modify health care and adapt it to an integrated school setting; when and how to implement procedures to attain the desired educational outcomes; and how and to whom to provide training, monitoring, and evaluation. (p. 181)

The composition of the team, while variable, many include the parent, the nurse, and special educator. If the student does not receive special education services, a regular educator is a member of the team, instead of a special educator. When students have special educational needs and are integrated into general education programs, both teachers are often included. When students receive occupational and physical therapies, personnel from those critical disciplines are also frequently represented.

Initial planning for a child who is transitioning from a hospital to a school is successfully augmented with hospital personnel charged with the responsibility of that transition. They can be invaluable in preparing school personnel, families, and students in creating a safe and comfortable transition for all involved

While the transdisciplinary model is characterized by shared leadership (Orelove \& Sobsey, 1991), typically one member of a health care planning team assumes coordination responsibility. In many cases, a school nurse assumes that role. While that may appear to be a logical choice, many districts do not have sufficient school nursing coverage available to them. In those cases, teachers, social workers, or parents assume that coordination responsibility.

The team's function is to identify the questions for each child, to develop sound answers to those questions, and to develop communication systems for monitoring and adjusting solutions in response to changing conditions. Difficult questions addressed by the team include identifying health concerns, determining who is responsible for implementing what aspects of the student's care, and identifying the training needed for responsible personnel.

Decisions regarding health care needs must be based on information received from the students' physicians in the form of specific prescriptions. We recommend that prescriptions include:

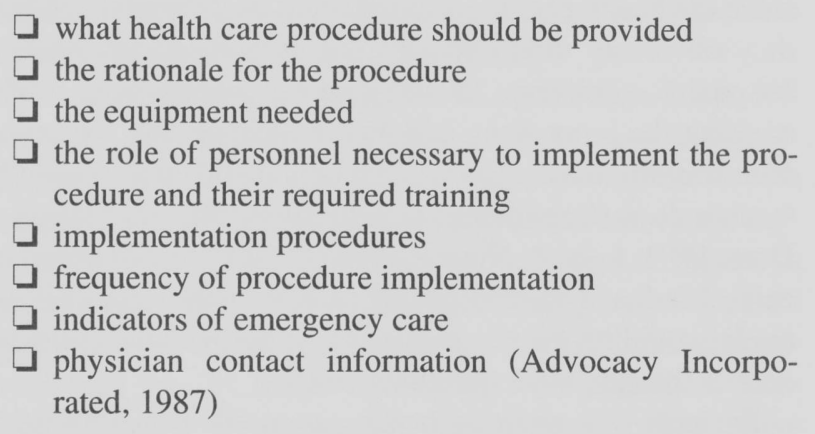

Many districts recognize the critical role of the family in determining the health care needs of their child at school. While written prescriptions and materials are helpful, ultimately it is the parents who can identify the most effective ways to meet their child's needs. Frequent ongoing contact with families enable the exchange of this critical information.

Once the needs are identified, the question becomes who is responsible for implementing health care procedures - the school nurse, the teacher, the paraprofessional, or a health care aide? Issues about this decision focus on the "medicalness" of the procedure and, consequently, the question of who can develop the expertise to deliver the procedure (Department of Education, State of Hawaii v. Door, 1983; 
Detsel v. Board of Education, 1987; Tatro v. Irving Independent School District, 1984). Additional concern is expressed about the role of a teacher relative to students with complex health care needs (Lehr \& Macurdy, in press). Given all the responsibilities of a teacher, is he or she also responsible for attending to the ongoing health care needs of students?

Professionals differ in their opinions of who should implement procedures. Some believe the team should have primary decision-making responsibility to determine the most appropriate individual to deliver procedures (Sobsey \& Cox, 1991). Others base their decisions on state-regulated nursing practice acts that regulate the provision of health care. Still others base the decision on published guidelines developed by a joint task force represented by the American Federation of Teachers, the Council for Exceptional Children, the National Association of School Nurses, Inc., and The National Education Association (Joint Task Force for the Management of Children with Special Health Care Needs, 1990). The guidelines specify roles and responsibilities for many of the health care procedures that are increasingly being provided in schools. These guidelines are based on descriptions of procedures and not necessarily on individual assessments of the needs of a child, which are often better determined by a team review of a child's unique needs (Lehr \& Macurdy, in press; Sobsey \& Cox, 1991).

While there are differences of opinion about who should implement particular procedures for particular students, there is consensus that this person should be competent and that training should be provided to a range of personnel to develop different levels of awareness and skill.

Palfrey et al. (1992) recommended two types of training - general and child-specific. General training is designed to demystify the student's health care needs and to provide sufficient information for those not directly responsible for health care services to respond to emergencies. Since neither regular education teachers like Mrs. Philpot, nor special education teachers, were trained in health care in their preservice programs (and this remains the status quo), information must be provided to school personnel through inservice training (Lehr, 1990b). Training of this nature should be provided to all building personnel, not just professional staff, and should include secretaries, cafeteria personnel, bus drivers, and custodial staff.

Child-specific training is for those who assume health care implementation responsibilities. Many manuals detail protocols for implementing health care procedures, but most teams recognize that reading the manual alone is not sufficient to become competent (Lehr \& Macurdy, in press).
Training must be provide by qualified health care professionals who utilize a competency-based model in which trainees demonstrate specific skill proficiency during initial training and at later periodic intervals.

Many teams have organized their own written health care plans. Similar to an IEP that articulates the ways an individual's educational needs will be met, a health care plan specifies the ways an individual's health care needs should be met (Lehr \& Macurdy, in press; Palfrey et al., 1992). The specifics of plans vary, depending on the needs of the student. Palfrey et al. (1992) recommend that for each individual child, they should include the following:

$\square$ a brief health history

$\square$ a specification of special health care needs

$\square$ a statement of the baseline health status

$\square$ a description of the medications and special dietary needs

$\square$ the transportation requirements of the child's special equipment needs

$\square$ a description of possible problems and interventions and emergency plans for both school and transit

$\square$ documentation of contact with local fire department, EMT services, and emergency rooms.

A health care plan is more comprehensive than a prescription that focuses exclusively on the health care procedure itself. In the development of a health care plan, particular attention is paid to emergency procedures, not just those related to the specific procedure, but also to fires and other such emergencies.

Communication is key to effective team functioning. Health care plans that specify certain procedures in writing do much to assure that critical information is communicated in a clear manner to team members. Ongoing communication regarding the effectiveness of the plans is critical, as is the observation, recording, and communicating of the health status of the students. Information must be shared between the home and school, and vice versa, on a frequent and systematic basis.

\section{EDUCATIONAL NEEDS}

\section{"How do I teach him?"}

The educational needs of students with complex health care needs vary, as do the educational needs of all students. Some require special educational services; others do not. Some have IEPs; others do not. 
For many students with health care needs, absenteeism is a problem. They may need to be away for short periods during the day to receive specific health care or therapies that cannot be provided in the classroom. Recurring periods of acute illness may require short term or extended periods of time away from school. Some students may experience fatigue and reduced stamina. Regardless of the reason, educational accommodations must be made during those periods of absences.

Most states have regulations governing the provision of home or hospital instruction for students who cannot attend school for prolonged periods of time. This form of educational service is often provided under special education laws and requires that students with special education needs be identified before they can receive those services. Students with complex health care needs who are not also identified as having special education needs may not be eligible for home or hospital instruction. A problem may also occur when regulations require that students miss a minimum number of school days before home- or hospital-based service can be provided. Sometimes home stays are not long enough to meet the minimum-day criteria; absences may be brief, but frequent enough to disrupt education. Students with complex health care needs require flexible systems, ones that can adjust to the frequently changing educational needs of the students (Lynch, Lewis, \& Murphy, 1992).

Adjustments may also need to be made to the curriculum in terms of content and instructional methodology. When frequent absences occur, students, teachers, and families often feel pressured by the need to "get it all in" - to cover all the same material as the rest of the class. For some students, it is helpful to distinguish between the material that the student should master and that which he or she will be exposed to, but not held accountable for learning. While this is a difficult process, it can result in clarity of focus and relief on the part of students, teachers, and family.

Modifications similar to those that are frequently recommended for students with special educational needs are used for students with complex health care needs. Alternative methods of participating in classroom work are necessary, as may be modifications of usual assignments. For some students, teachers may need to change standard grading policies.

Often, specific instructional objectives are targeted that relate directly to students' health care needs. (Lehr \& Macurdy, in press). Some students assume responsibility for their own health care procedures by indicating the need for administration of procedures, instructing others to implement procedures, or learning to self-administer procedures, such as tube feeding or catheterization.
Emphasis must often be placed on students' social emotional development. Children with complex health care needs who are entering school for the first time may have had their needs met exclusively by adults and had few opportunities to interact with peers in a regular school setting. Children who have ongoing health care needs as a result of a recent accident or injury may need support to adjust to their changed health or physical status.

The focus thus far has been on educational accommodations designed to help the student with complex health care needs. Many schools recognize the need to educate classmates to maximize all students' educational experiences. Formal "lessons" to teach students about medical conditions and the procedures involved in health care delivery are effective in eliminating fear and uncertainty. Health care materials included in the curriculum provide ongoing opportunities for increasing students' general understanding and sensitivity to students with complex health care needs. Teachable moments are often the most effective strategy for meeting students' urgent need to know!

\section{CHANGING VIEWS OF THE TYPICAL SCHOOL EXPERIENCE?}

\footnotetext{
"If he needs a machine to help him breath, isn't he too sick to be at school?"
}

Education of students with complex health care needs requires that district personnel change some views, particularly those related to the concept of sickness. The typical view of a child who requires a respirator, or who must be fed through a tube, is that he or she is seriously ill. Educators should be encouraged to develop an alternative viewpoint - that these are merely children who eat and breathe in different ways. In fact, it can be thought that these alternative methods of accomplishing functions make the child well; that without tube feeding, the child would be sick. This is not to say that children with complex health care needs do not become ill; they do and sometimes at higher rates than the general population (Orelove and Sobsey, 1991). The point is that we must begin with a view that the child is not sick, but utilizes health care support, sometimes in the form of technology to maintain health.

The term medically fragile is one that must be carefully considered because of its power in frightening school personnel. Webster's defines fragile as "easily broken or destroyed." Many, however, who work with students who are the focus of this article remark about the resilience of these 
children. Many of these children can be seen as incredibly strong - survivors of many adverse conditions, who in fact are not fragile at all, but remarkably strong to be able to rebound from periods of acute illness.

Some refer to the students discussed in this article as chronically ill. We prefer to refer to the students as having complex health care needs for two specific reasons. First, as previously discussed, often the children are not ill. They are healthy because of the health care provided. Second, the term, student or child with complex health care needs, conforms with the preference in the disability field to use language that focuses positive attention on the person and not the disability. Language that emphasizes the support a child needs, rather than the child's condition, can affect individuals' views of the child.

Normalization of school life for a child with complex health care needs is often a function of careful attention to previously addressed areas: our personnel perspectives; a transdisciplinary team with a good health care plan; and an educational program that is responsive to the individual needs of the student. It is a function of careful planning, systematic training for teachers, staff, and children, and general preparedness to meet the needs of each individual child at school. Often, it is a function of time.

"When I first saw the tube going directly into his stomach I was really nervous. As the nurse was describing everything to me I just couldn't get a picture of him in my classroom or me doing the tube feeding. As she [the nurse] talked me through it I took a deep breath and hooked him up. Over time it got easier. Robert has had his g-tube for almost 2 years now and his feedings are just as much a part of the daily routine as anything else. $H e$ 's gained weight and he's so much healthier now. I'm actually much more comfortable with giving the gtube feedings than I ever was with his drinking by mouth once his swallowing abilities started to decrease. The tube is much safer for him and easier for staff."

\section{REFERENCES}

Advocacy Incorporated. (1987). School health services. (Report \#143). Austin, TX: Author.

Council for Exceptional Children. (1988). Report of the Council for Exceptional Children's Ad Hoc Committee on Medically Fragile Students. Reston, VA: Author.

Department of Education, State of Hawaii v. Dorr. U.S. District Court, 727 F.2nd 809 (9th. Cir.1983).
Detsel v. Board of Education, 820 F. 2 d. 587 (2d Cir.1987).

Golinker, L. (1991, August). Memorandum re. final settlement agreement in Pullen v. Cuomo. Washington, DC: United Cerebral Palsy Associations.

Joint Task Force for the Management of Children with Special Health Care Needs. (1990). Guidelines for the delineation of roles and responsibilities for the safe delivery of specialized health care in the educational setting. Reston, VA: Council for Exceptional Children.

Koop, C. E. (1987). Children with special health care needs. Washington, DC: U. S. Department of Health and Social Services.

Lehr, D. H. (1990a). Educating students with special health care needs. In E. L. Meyen (Ed.), Exceptional children in today's schools (pp. 107-130). Denver: Love Publishing.

Lehr, D. H. (1990b). Personal preparation to serve children with special health care needs. In A. Kaiser \& C. McWhorter (Eds.), Critical issues in preparing personnel to work with persons who are severely handicapped (pp. 135-151). Baltimore: Paul H. Brookes.

Lehr, D. H., \& Macurdy, S. (in press). Special health care needs. In M. Agran, N. Marchand-Martella, \& R. Martella (Eds.), Health and safety for persons with disabilities: Applications across community settings. Baltimore: Paul H. Brookes.

Lehr, D., \& Noonan, M. J. (1989). Issues in the education of students with complex health care needs. In F. Brown and D. H. Lehr (Eds.), Persons with profound disabilities: Issues and practices (pp. 139-158). Baltimore: Paul H. Brookes.

Levy, S. E., \& Pilmer, S. (1992). The technology-assisted child. In M. L. Batshaw \&Y. M. Perret (Eds.), Children with disabilities: A medical primer (pp. 137-158). Baltimore: Paul H. Brookes.

Lynch, E. W., Lewis, R. B., \& Murphy, D. S. (1992). Educational services for children with chronic illnesses: Perspectives of educators and families. Exceptional Children, 59(3), 210-220.

Office of Technology Assessment. (1987). Technology dependent children: Hospital $v$. home care-A technical memorandum. Washington, DC: U. S. Government Printing Office.

Orelove, F. D., \& Sobsey, D. (Eds.) (1991). Educating children with multiple disabilities. Baltimore: Paul H. Brookes.

Palfrey, J. S., Haynie, M., Porter, S., Bierle, T., Cooperman, P., \& Lowcock, J. (1992). Project School Care: Integrating children assisted by medical technology into educational settings. Journal of School Health, 62(2), 50-54.

Sirvis, B. (1988). Students with special health care needs. Teaching Exceptional Children, 20(4), 40-44.

Shelton, T. L., Jeppson, E. S., \& Johnson, B. H. (1987). Family centered care for children with special health care needs. Washington, DC: Association for the Care of Children's Health.

Sobsey, D., \& Cox, A. W. (1991). Integrating health care and educational programs. In F. P. Orelove \& D. Sobsey (Eds.), Educating children with multiple disabilities (pp. 187-231). Baltimore: Paul H. Brookes.

Stainback, W., \& Stainback, S. (1992). Restructuring for caring and effective education: An administrative guide to creating heterogeneous schools. Baltimore: Paul H. Brookes.

Tatro v. Irving Independent School District. 468, U. S. 883 (1984).

Urbano, M. T. (1992). Preschool children with special health care needs. San Diego: Singular Publishing.

Viadero, D. (1987, March). 'Medically fragile' students pose dilemma for school officials. Education Week, 1, 14. 


\section{Professional update}

\section{April 5-9, 1993}

Council for Exceptional Children Annual Convention

San Antonio Convention Center

San Antonio, Texas

Contact: CEC

1920 Association Drive

Reston, Virginia 22091

(703) 264-9468

\author{
May 4-7, 1993 \\ Young Adult Institute \\ International Conference \\ Meeting the Challenges in \\ Developmental Disabilities \\ Crowne Plaza Hotel \\ New York City \\ Contact: YAI \\ 460 West 34th Street \\ New York, NY 10001 \\ (212) 563-7474
}

\section{PERMISSIONS AND COPYRIGHT}

All rights are reserved. No part of this publication may be reproduced, photocopied, faxed, stored in a retrieval system, or transmitted, in any form or by any means, electronic, mechanical, recording or otherwise, without the prior written permission of the publisher. Back issues are available for sale. Reproduction requires permission and payment of fees. It is illegal and a violation of Federal copyright law to reproduce this publication without permission. Direct all inquiries to the permissions editor. 